\title{
Anaerobic ammonium oxidation in traditional municipal wastewater treatment plants with low-strength ammonium loading: Widespread but overlooked
}

\author{
Shanyun Wang ${ }^{\text {a }}$, Yongzhen Peng ${ }^{\text {a, b, * }}{ }^{\text {, Bin Ma }}{ }^{\text {b }}$, Shuying Wang ${ }^{\text {b }}$, Guibing Zhu ${ }^{c}$ \\ a State Key Laboratory of Urban Water Resource and Environment, Harbin Institute of Technology, Harbin 150090, China \\ b Key Laboratory of Beijing for Water Quality Science and Water Environment Recovery Engineering, Engineering Research Center of Beijing, Beijing \\ University of Technology, Beijing 100124, China \\ c Key Laboratory of Drinking Water Science and Technology, Research Center for Eco-Environmental Sciences, Chinese Academy of Sciences, Beijing 100085, \\ China
}

\section{A R T I C L E I N F O}

\section{Article history:}

Received 16 April 2015

Received in revised form

28 June 2015

Accepted 3 July 2015

Available online 6 July 2015

\section{Keywords:}

Anammox

Abundance

Rate

Municipal wastewater treatment plants

Low-strength ammonium loading

Anthropogenic ecosystems

\begin{abstract}
A B S T R A C T
Occurrence of anaerobic ammonium oxidation (anammox) in marine and freshwater systems has greatly changed our understanding of global nitrogen $(\mathrm{N})$ cycle and promoted the investigation of the role and ecological features of anammox in anthropogenic ecosystems. This study focused on the spatio-temporal abundance, activity, and biodiversity of anammox bacteria in full-scale municipal wastewater treatment plants (WWTPs) via traditional nitrification/denitrification route with low-strength ammonium loading. The anammox bacteria were detected in all the treatment units at the five WWTPs tested, even in aerobic zones (dissolved oxygen $>2 \mathrm{mg} \mathrm{L}^{-1}$ ) with abundance of $10^{5}-10^{7}$ hydrazine synthase ( $h z s$ ) gene copies $\mathrm{g}^{-1}$. The ${ }^{15} \mathrm{~N}$-isotope tracing technology revealed that the anammox rates in WWTPs ranged from 0.08 to $0.36 \mu \mathrm{mol} \mathrm{N} \mathrm{g}{ }^{-1} \mathrm{~h}^{-1}$ in winter and $0.12-1.20 \mu \mathrm{mol} \mathrm{N} \mathrm{g}{ }^{-1} \mathrm{~h}^{-1}$ in summer with contributions of 2.05 $-6.86 \%$ and $1.71-7.26 \%$ to $\mathrm{N}_{2}$ production, respectively. The diversity of anammox bacteria in WWTPs was distributed over only two genera, Brocadia and Kuenenia. Additionally, the exploration of potential interspecies relationships indicated that ammonia oxidation bacteria (AOB) was the major nitritesubstrate producer for anammox during nitrification, while Nitrospira, a nitrite oxidation bacteria (NOB), was the potential major competitor for nitrite. These results suggested the contribution of $\mathrm{N}$ removal by the widespread of anammox has been overlooked in traditional municipal WWTPs, and the ecological habitats of anammox bacteria in anthropogenic ecosystems are much more abundant than previously assumed.
\end{abstract}

(C) 2015 Elsevier Ltd. All rights reserved.

\section{Introduction}

Biogeochemical nitrogen $(\mathrm{N})$ cycle is primarily driven by diverse microorganisms (Falkowski et al., 2008). Denitrification by heterotrophic bacteria has been regarded as the only pathway for the loss of fixed nitrogen to the atmosphere (Burgin and Hamilton, 2007). This concept has been challenged by the discovery of anaerobic ammonium oxidation (anammox) mediated by autotrophic anammox bacteria capable of oxidizing ammonia directly to

\footnotetext{
* Corresponding author. State Key Laboratory of Urban Water Resource and Environment, Harbin Institute of Technology, Harbin 150090, China.

E-mail address: pyz@bjut.edu.cn (Y. Peng).
}

nitrogen gas $\left(\mathrm{N}_{2}\right)$ without emission of nitrous oxide $\left(\mathrm{N}_{2} \mathrm{O}\right)$ (Kuypers et al., 2003; Dalsgaard et al., 2003; Kartal et al., 2011).

Anammox has been detected in many natural ecosystems worldwide. In marine systems, the anammox is ubiquitous at the hotspots occurring in oxygen minimum zones (OMZ) (Dalsgaard et al., 2003; Ward et al., 2009; Pitcher et al., 2011; Hannig et al. 2007; Lam et al., 2007), and has been found to be responsible for up to 50\% of marine N loss (Thamdrup and Dalsgaard, 2002; Arrigo, 2005). Anammox have also been detected ubiquitously in freshwater systems at all levels of substrate concentration (Zhu et al., 2013; Schubert et al., 2006; Wang et al., 2012a; Zhang et al., 2007), and neither temperature nor substrate-loading affected anammox occurrence (Zhu et al., 2013). These findings indicate that anammox may have a wide environmental habitat, and be 
responsible for a significant proportion of $\mathrm{N}_{2}$ production from natural ecosystems.

In addition, anammox processes have been detected in anthropogenic ecosystems, such as constructed wetlands (Zhu et al., 2011a), plant soil (Zhu et al., 2011b; Hu et al., 2011) and recirculation aquaculture systems (van Kessel et al., 2010; Tal et al., 2006). As the largest biotechnological application worldwide, municipal wastewater treatment plants (WWTPs) have played a great role in the $\mathrm{N}$ cycle. However, these systems contributed to $1.3 \%$ of the total Nitrous oxide $\left(\mathrm{N}_{2} \mathrm{O}\right)$ emitted (IPCC, 2001). Nevertheless, it is still not clear whether anammox occurrence is widespread in conventional municipal WWTPs, which could be significant for understanding the global $\mathrm{N}$ cycle balance and $\mathrm{N}$-flux calculation model.

Based on previous studies (Zhu et al., 2013, 2011a, 2011b; Wang et al., 2012a; Zhu et al., 2011a, Zhu et al., 2011b), a new hypothesis was raised in this study, that is anammox occurs in conventional municipal WWTPs with low-ammonium loading. Although the anammox process has been widely used in high-strength (500-1500 $\mathrm{mg} \mathrm{NH}_{4}^{+}-\mathrm{N} \mathrm{L}^{-1}$ ) wastewater treatment (Lackner et al., 2014), it has been verified that substantial anammox activity could be maintained with reclaimed water (ammonia $<2 \mathrm{mg} \mathrm{L}^{-1}$ ) and undesirable $\mathrm{N}_{2} \mathrm{O}$ emissions could be reduced (Zhu et al., 2011a). Therefore, the distribution, contribution and microbial mechanism of anammox in municipal WWTPs were investigated in this study. Specifically, a total of 12 treatment units in five municipal WWTPs at the Northern China were investigated for the occurrence of anammox using molecular and ${ }^{15} \mathrm{~N}$ isotope tracing techniques. The results were compared in terms of treatment processes, treatment capacities, operation modes and seasonal variations. In addition, the interspecies relationships among anammox bacteria and nitrifiers (ammonia oxidation bacteria (AOB) and archaea (AOA), nitrite oxidation bacteria (NOB)) were analyzed. The ubiquitous nature and substantial contribution of anammox processes to conventional municipal WWTPs were verified for the first time.

\section{Material and methods}

\subsection{Municipal WWTPs and samples}

A total of twenty-four seasonal samples (12 samples in summer and 12 samples in winter) were collected from all 12 treatment units at five municipal WWTPs that employ different treatment processes including anaerobic/anoxic/oxic process (AAO) at the Xiaohongmen WWTP, anaerobic/anoxic/oxic process (AAO) at the Gaobeidian WWTP, oxidation ditch process (OD) at the Jiuxianqiao WWTP, a membrane bio-reactor (MBR) at the Beixiaohe WWTP, and a sequencing batch reactor (SBR) at the Wujiacun WWTP. Detailed information regarding the long-term operation of these five WWTPs, including flow rate, suspended solids (ss), sludge retention time (SRT), hydraulic retention time (HRT), temperature (T), dissolved oxygen (DO), and $\mathrm{pH}$, are listed in the Table S1. The samples were collected at the treatment units at least in triplicate, and transported to the laboratory on ice. A portion of each sample was used to determine the anammox activity, while the remainder was used for chemical analyses and subsamples were stored at $-80{ }^{\circ} \mathrm{C}$ for later DNA extraction and molecular analysis.

\subsection{Chemical analyses}

The ammonium $\left(\mathrm{NH}_{4}^{+}-\mathrm{N}\right)$, nitrite $\left(\mathrm{NO}_{2}^{-}-\mathrm{N}\right)$ nitrate $\left(\mathrm{NO}_{3}^{-}-\mathrm{N}\right)$ and total nitrogen (TN) contents were measured using an Automated Ion Analyzer FIA (QuickChem 8500, Lachat Instruments, Milwaukee, WI, USA). The dissolved oxygen (DO), pH and temperature $(\mathrm{T})$ were monitored in-situ using a WTW oxi/340i oxygen probe (WTW Company, Weilheim, Germany). The chemical oxygen demand (COD) and mixed liquid volatile suspended solids (MLVSS) were determined according to the standard methods (APHA et al., 1995). The detailed sample characteristics of the treatment units at five municipal WWTPs are listed in Table S2.

\subsection{Measurement of anammox and denitrification rate with ${ }^{15} \mathrm{~N}$ isotopic tracing technique}

Mixed sludge-liquid samples of municipal WWTPs samples were added to He-flushed, $12.6 \mathrm{~mL}$ glass vials (Exetainer, Labco, High Wycombe, Buckinghamshire, UK), after which they were mixed with $\mathrm{N}_{2}$-purged in-situ wastewater and pre-incubated at ambient temperature (summer $\left(25 \pm 0.9{ }^{\circ} \mathrm{C}\right)$ and winter $\left(13 \pm 1.3^{\circ} \mathrm{C}\right)$, except for those from digested sludge that were incubated at $30 \pm 1.1{ }^{\circ} \mathrm{C}$ in summer and $24 \pm 0.7^{\circ} \mathrm{C}$ in winter) for 24-36 h to deplete residual $\mathrm{NO}_{\mathrm{x}}^{-}$and oxygen. Subsequently, $100 \mu \mathrm{l}$ of $\mathrm{N}_{2}$-purged stock solution of each isotopic mixture ((i) ${ }^{15} \mathrm{NH}_{4}^{+}$ $\left(>99.6 \%{ }^{15} \mathrm{~N}\right)$, (ii) ${ }^{15} \mathrm{NH}_{4}^{+}+{ }^{14} \mathrm{NO}_{3}^{-}$and (iii) ${ }^{14} \mathrm{NH}_{4}^{+}+{ }^{15} \mathrm{NO}_{3}^{-}(>99.0 \%$ $\left.{ }^{15} \mathrm{~N}\right)$ ) was injected through the septa of each vial to reach a final concentration of $50 \mathrm{mg} \mathrm{L}^{-1}$ close to the in-situ TN concentration of 50-65 $\mathrm{mg} \mathrm{L}^{-1}$ (Zhu et al., 2013, 2011a, 2011b). Incubation of the samples at ambient temperatures was interrupted at various time points ( $0 \mathrm{~h}, 4 \mathrm{~h}, 8 \mathrm{~h}, 16 \mathrm{~h}$, and $32 \mathrm{~h}$ ) by injecting $200 \mu \mathrm{L}$ of $7 \mathrm{M} \mathrm{ZnCl}_{2}$ solution to inhibit the biological activity in the Exetainer. The evolution of ${ }^{28} \mathrm{~N}_{2},{ }^{29} \mathrm{~N}_{2}$ and ${ }^{30} \mathrm{~N}_{2}$ in nitrification, denitrification and anammox processes involving labeled/unlabelled $\mathrm{NH}_{4}^{+}$and $\mathrm{NO}_{\mathrm{x}}^{-}$ was shown in Fig. 1 and Fig. S1. The potential contribution of anammox and denitrification to $\mathrm{N}_{2}$ production (or $\mathrm{N}$ removal) were then calculated based on the output ${ }^{29} \mathrm{~N}_{2}$ and ${ }^{30} \mathrm{~N}_{2}$, which were measured by the continuous flow isotope ratio mass spectrometry using a MAT 253 system with Gasbench II and an autosampler (Bremen, Thermo Electron Corporation, Finnigan, Germany) (Thamdrup and Dalsgaard, 2002). The ratio of anammox role ( $R a \%)$ was calculated by the potential contribution via anammox to total $\mathrm{N}$ removal (anammox plus denitrification).

\subsection{DNA extraction, PCR, cloning, sequencing, and phylogenetic analysis}

Genomic DNA was extracted from $0.2 \mathrm{~g}$ MLVSS of each dry samples using a FastDNA ${ }^{\mathbb{B}}$ SPIN Kit for Soil (QBIOgene Inc., Carlsbad, CA, USA) with a beating time of $45 \mathrm{~s}$ and a speed of 5.5. PCR was conducted to detect anammox 16S rRNA genes listed in Table S3, after which the purified PCR products were ligated and cloned using the pGEM ${ }^{\mathbb{R}}$-T Easy system (Promega, Madison, WI, USA). One hundred clones were picked from each of the PCR products. The inserts were analyzed using T7 and SP6 vector primers and the positive amplicons were analyzed by restriction endonucleases Hae III and Hha I (Promega, Madison, WI, USA). Clones of representative digestion patterns were selected for sequencing and deposited in GenBank (KM609124-KM609183). All sequences and their relatives obtained from an NCBI-BLAST search of the GenBank database were then aligned using Clustal X 1.83 (Thompson et al., 1997). The phylogenetic trees were constructed by neighbor-joining (NJ) with the Jukes-Cantor correction using the MEGA 4.0 package (Tamura et al., 2007).

\subsection{Quantitative PCR assay}

The abundance of anammox bacteria, nitrifiers (AOA, AOB, and NOB) and total bacteria were determined using a Stratagene Mx3005p QPCR system (Agilent Technologies, USA) with the SYBRGreen approach (TAKARA, Dalian, China). The hydrazine synthase (hzs) function gene of anammox, amoA function gene of AOA and 


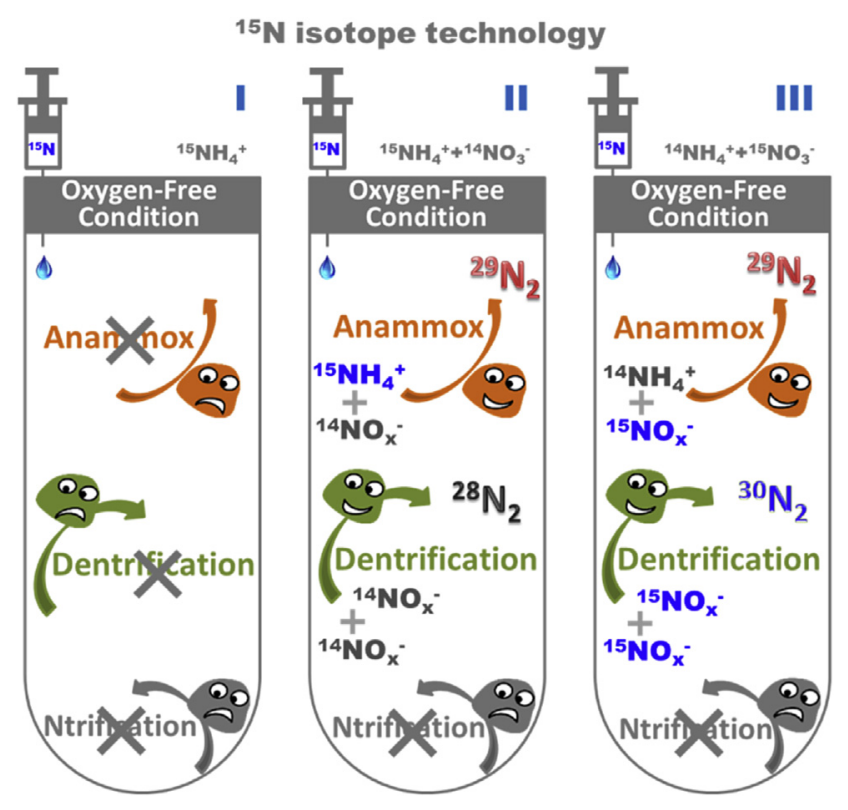

Fig. 1. The evolution of ${ }^{28} \mathrm{~N}_{2},{ }^{29} \mathrm{~N}_{2}$ and ${ }^{30} \mathrm{~N}_{2}$ in nitrification, denitrification and anammox processes involving labeled/unlabelled $\mathrm{NH}_{4}^{+}$and $\mathrm{NO}_{\mathrm{x}}^{-}$.

AOB, 16S rRNA genes of NOB (nib and nis for Nitrobacter and Nitrospira, respectively) and universal bacterial 16S rRNA genes for total bacteria were amplified using the HSBeta396F/HSBeta742R (Zhu et al., 2013; Wang et al., 2012b), Arch-amoAF/Arch-amoAR (Wang et al., 2011), amoA-1f/amoA-2r (Wang et al., 2011), FGPS872f/FGPS1269r (Ahn et al., 2008), 341f/NTSPAr (Geets et al., 2007) and 341f/535r (Koike et al., 2007) respectively. Amplification was performed in $25 \mu \mathrm{L}$ reaction mixtures that consisted of 12.5 $\mu$ L SYBR $^{\circledR}$ Premix Ex Taq ${ }^{\mathrm{TM}}$ (Takara, Dalian, China), $1 \mu$ L bovine serum albumin ( $\left.25 \mathrm{mg} \mathrm{mL}^{-1}\right), 1 \mu \mathrm{L}$ each primer $(10 \mu \mathrm{M})$, and $2 \mu \mathrm{L}$ DNA templates (1-10 $\mathrm{ng}$ ). The detailed amplification protocols are listed in Table S3.

Standard curves were obtained from ten-fold serial dilutions of the plasmid DNAs after determining of their concentrations using a Nanodrop ND-1000 UV-Vis Spectrophotometer (NanoDrop Technologies, Wilmington, DE, USA). The standard curves were employed when they covered 5-7 orders of magnitude with amplification efficiency and correlation coefficients above $95 \%$ and 0.98 , respectively. Triplicate data assays were performed for the decimally diluted standard plasmids, properly diluted samples, and negative controls.

\subsection{Statistical analysis}

Sequences (based on 3\% nucleotide cut-off) were grouped into the same operational taxonomic unit (OTU) using the DOTUR software by the furthest neighbor approach (Schloss and Handelsman, 2005). Biodiversity indicators (rarefaction, Shannon's diversity index, Simpson's diversity index, and the Chao1 estimator) were calculated using the DOTUR software. The pearson correlation and graphing were achieved using SPSS version 16.0 and Origin 7.5 software, respectively.

\section{Results}

\subsection{Distribution and abundance of anammox bacteria in municipal WWTPS}

Prior to the investigation of the seasonal occurrence of anammox in municipal WWTPs, it is necessary to confirm the presence of anammox bacteria. PCR analysis of the 16S rRNA genes of Planctomycetes and anammox bacteria confirmed that all clones represented anammox-like sequences, which indicated that anammox bacteria were present in all 24 samples collected from 12 treatment units at five municipal WWTPs.

The abundance of anammox bacteria in the municipal WWTPs was directly estimated by a qPCR assay targeting the $h z s$ gene which is specific for anammox bacteria (Fig. 2). The abundance of anammox bacteria was higher in summer $\left(4.25 \times 10^{5}-1.15 \times 10^{7}\right.$ copies $\mathrm{g}^{-1},<0.03 \%$ of the total bacteria, $n=12$ ) than in winter $\left(2.49 \times 10^{5}-1.99 \times 10^{6}\right.$ copies $\mathrm{g}^{-1},<0.03 \%$ of the total bacteria, $n=12$ ) with the seasonal ratio of 1.0-20.6, which showed a strong spatiotemporal heterogeneity (Fig. 2, Fig. S2, S3). The abundance of anammox bacteria was the highest in activated sludge tanks with remarkable seasonal variation. The primary setting tanks held the second highest abundance with smaller seasonal change (an

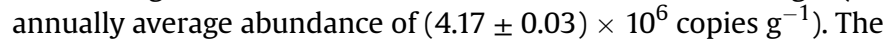
anammox bacterial abundance in the remaining two units (aerated grit chambers and sludge digestion tanks) was only on the order of $10^{5}$ and experienced little fluctuations with seasons (Fig. 3, Fig. S2). Among five WWTPs, the abundance of anammox bacteria was higher in oxidation ditch process (up to $10^{7}$ copies $\mathrm{g}^{-1}$ in summer) and followed by anaerobic/anoxic/oxic process (annual average of 2.59-2.95 $\times 10^{6}$ copies $g^{-1}$ ) (Fig. 3, Fig. S2).

\subsection{Role and contribution of anammox to $N$ removal in municipal WWTPS}

To assess the rate of $\mathrm{N}$ removal associated with anammox at WWTPs, the samples were incubated under in situ temperature and analyzed by ${ }^{15} \mathrm{~N}$ isotope tracing technique. The results revealed there was no significant accumulation of ${ }^{15} \mathrm{~N}_{2}$-labeled gas $\left({ }^{29} \mathrm{~N}_{2}\right.$ and ${ }^{30} \mathrm{~N}_{2}$ ) in any WWTP sample amended with ${ }^{15} \mathrm{NH}_{4}^{+}$alone, indicating that all of the $\mathrm{NO}_{3}^{-}$was depleted by pre-incubation for 24-36 h (Fig. S1-I). When both ${ }^{15} \mathrm{NH}_{4}^{+}$and ${ }^{14} \mathrm{NO}_{3}^{-}$were added, ${ }^{29} \mathrm{~N}_{2}$ was accumulated in all samples, while there was no accumulation of ${ }^{30} \mathrm{~N}_{2}$, demonstrating that that the anammox occurred in these WWTPs (Fig. S1-II).

The rate and contribution of anammox to denitrification was investigated by incubating samples amended with ${ }^{14} \mathrm{NH}_{4}^{+}$and ${ }^{15} \mathrm{NO}_{3}^{-}$(Fig. S1-III). Active anammox $\left(0.08-1.2 \mu \mathrm{mol} \mathrm{N} \mathrm{g}{ }^{-1} \mathrm{~h}^{-1}\right)$ was detected in all samples, with the contributions of $2.05-6.86 \%$ and $1.71-7.26 \%$ to the total $\mathrm{N}_{2}$ production of each treatment unit $(R a \%)$ at summer and winter, respectively (Figs. 2 and 3, Fig. S2). The highest rate was detected in the primary setting tank of the WWTP employing the anaerobic/anoxic/oxic process in summer $\left(1.20 \mu \mathrm{mol} \mathrm{N} \mathrm{g}{ }^{-1} \mathrm{~h}^{-1}\right)$ and winter $\left(0.36 \mu \mathrm{mol} \mathrm{N} \mathrm{g} \mathrm{g}^{-1}\right)$, while the lowest rate was observed in aerated grit chambers of the WWTP employing the SBR $\left(0.12 \mu \mathrm{mol} \mathrm{N} \mathrm{g} \mathrm{N}^{-1} \mathrm{~h}^{-1}\right)$ in summer and the WWTP employing the anaerobic/anoxic/oxic process $\left(0.08 \mu \mathrm{mol} \mathrm{N} \mathrm{g}{ }^{-1} \mathrm{~h}^{-1}\right)$ in winter.

By combining the WWTP operational parameters and anammox rates, the potential contribution of anammox to $\mathrm{N}$ removal in municipal WWTPs was estimated (Table 1 and Table S4). The contribution of anammox ranged from $10^{-3} \mathrm{t} \mathrm{N} \mathrm{yr}^{-1}$ (aerated grit chamber) to $194.3 \mathrm{t} \mathrm{N} \mathrm{yr}^{-1}$ (activated sludge tank in summer), which counted for up to $6.6 \%$ of the total N removal in WWTPs, and was significantly correlated with the WWTPs' flow rate $\left(R^{2}=0.989\right.$, $p=0.001$, for summer; $R^{2}=0.938, p=0.018$, for winter; Table S5). This indicated that anammox is an important contributor for $\mathrm{N}$ removal but has been long-term overlooked, especially for largescale WWTPs. The anammox process in activated sludge tanks showed high cell-density, activity and N-removal contribution (above $85.2 \%$ of the total $\mathrm{N}$ removal via anammox in WWTPs) even 


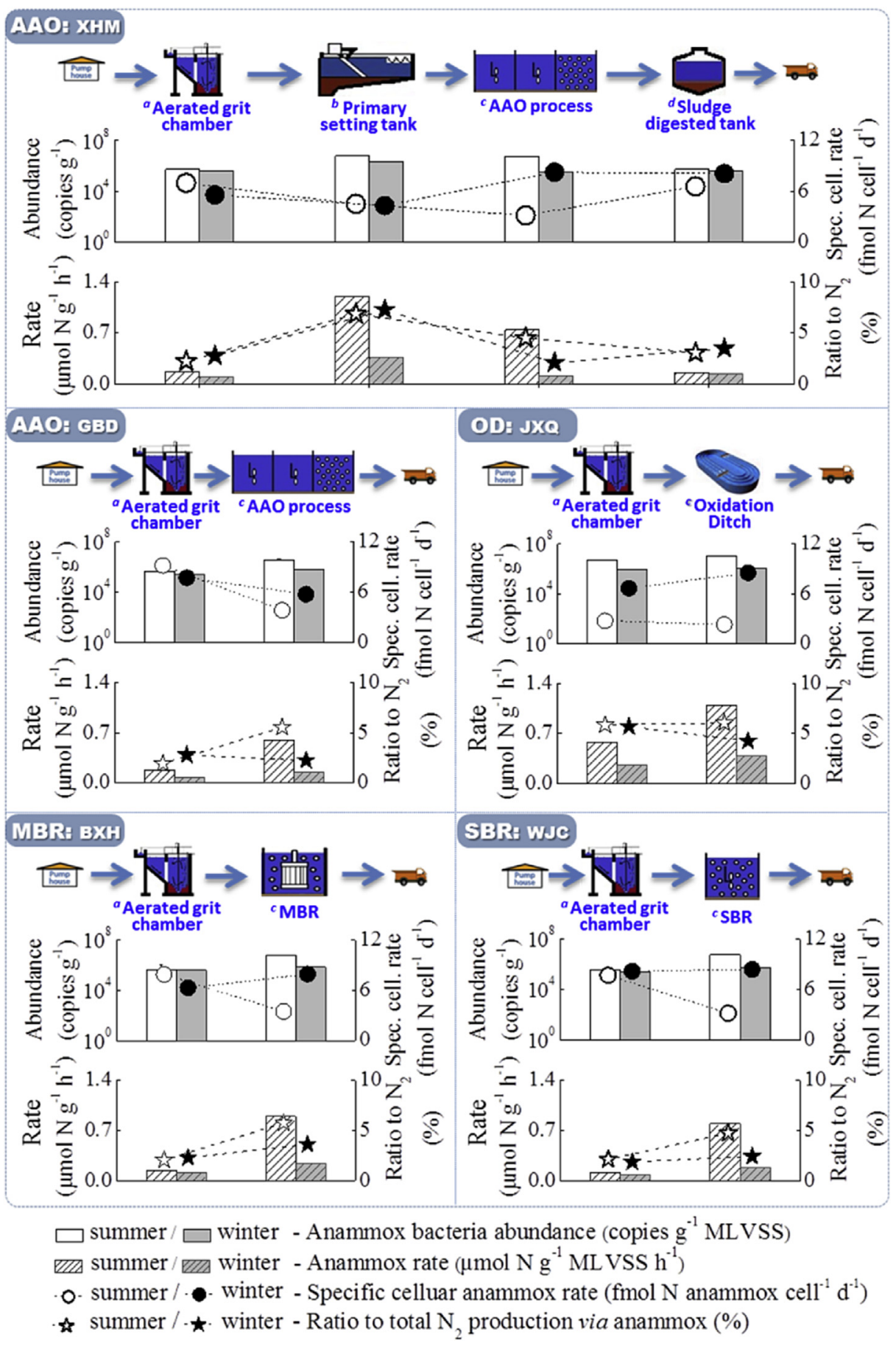

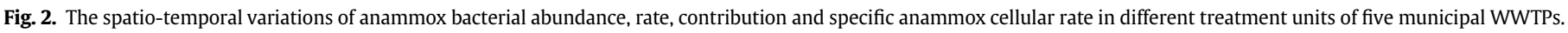
(Error bars indicate s.d. $(n=3)$ ).

under DO concentration higher than $2 \mathrm{mg} \mathrm{L}^{-1}$. Moreover, the contribution of anammox in summer (7.8-123.0 $\mathrm{t} \mathrm{N} \mathrm{yr}^{-1}, 4.2-6.6 \%$ contribution in WWTPs) was about 3.8-8.0 times higher than winter (1.0-35.2 $\mathrm{t} \mathrm{N} \mathrm{yr}^{-1}, 2.1-2.6 \%$ contribution in WWTPs) (Table 1 ), indicating that temperature might be an important factor for the large-scale anammox process. The pearson correlation analysis also showed that temperature had the most positive influence on anammox activity $\left(R^{2}=0.492, p=0.015\right)$, and COD loading had the most negative influence $\left(R^{2}=-0.418, p=0.042\right)$ (Table S7). Other operational parameters, including influent ammonia, influent nitrate, sludge retention time (SRT), hydraulic retention time (HRT) exhibited little influence on anammox activity, which further addressed that anammox might widespread occurred in WWTPs (Table S7).

The specific cellular anammox activities calculated based on anammox activity and abundance indicated the similar values in summer and winter. Specifically, the cellular rate was 2.36-9.20 fmol N cell ${ }^{-1} \mathrm{~d}^{-1}$ with an average of $5.46 \pm 2.31 \mathrm{fmol} \mathrm{N}$ cell $^{-1} \mathrm{~d}^{-1}(n=12)$ in summer, while it was 5.59-9.52 $\mathrm{fmol} \mathrm{N} \mathrm{cell}^{-1}$ $\mathrm{d}^{-1}$ with an average of $7.20 \pm 1.42 \mathrm{fmol} \mathrm{N}$ cell $^{-1} \mathrm{~d}^{-1}(n=12)$ during 


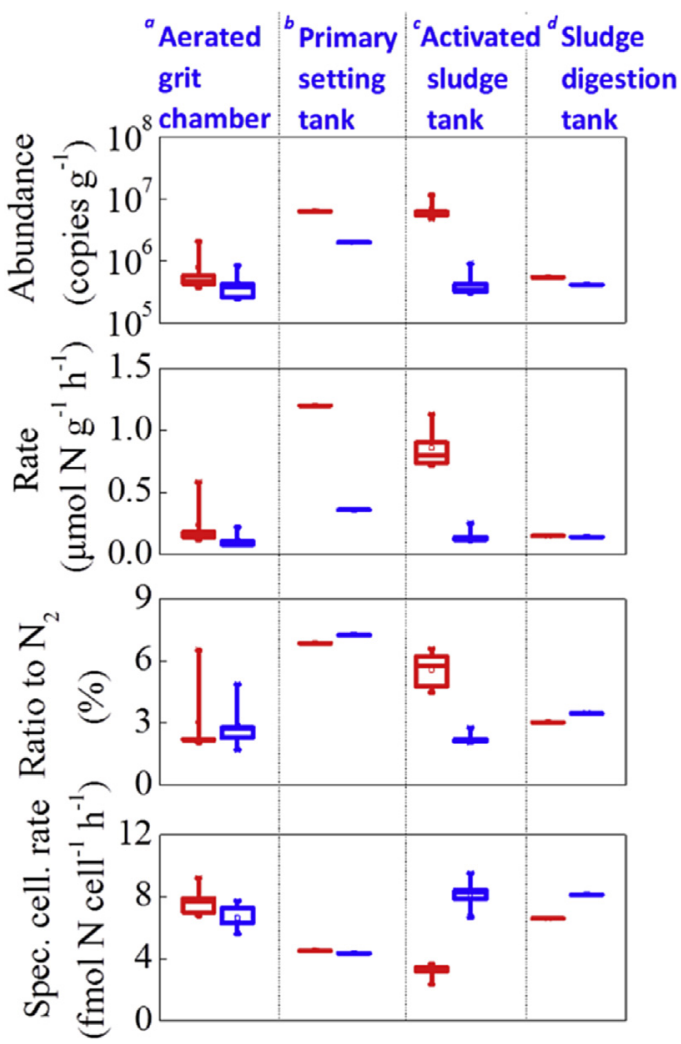

Fig. 3. The related statistical analysis of the spatio-temporal variations of anammox bacterial abundance, rate, contribution, and specific cellular rate in different treatment units of five municipal WWTPs. Box charts (horizontal line indicates the median, box gives the 25th and 75th percentiles, and whisker shows range from the 5th to 95th percentile) of anammox $h z s$ gene abundance, anammox rate, ratio of anammox contribution to $\mathrm{N}_{2}$ production (N-removal) and specific anammox cellular rate $(n=5)$.

winter (Figs. 2 and 3, Fig. S2), indicating that the anammox cellular activity in WWTPs was stable.

\subsection{Community of anammox bacteria in municipal WWTPS}

To investigate the community structure of anammox bacteria, the 16S rRNA gene sequences retrieved from the clone libraries of different units of WWTPs were analyzed using the Chao1 estimator and Shannon's and Simpson's diversity indices. The results showed that the biodiversity of anammox bacteria was low in municipal WWTPs, with only 8 OTUs being obtained based on 60 representative sequences, as well as a Chao1 estimator value of 8.5 , Shannon's index score of 1.52, and Simpson's index value of 0.30 (Fig. 4, Table S6). The phylogenetic analysis revealed that the anammox bacteria in WWTPs were related to only two genera, Brocadia (81.7\%) and Kuenenia (18.3\%). The oxidation ditch process possessed a higher anammox bacterial diversity than the other processes in municipal WWTPs (Table S6).

\subsection{Potential interactions between anammox bacteria and nitrifiers}

Nitrite, rather than nitrate, is the preferred substrate for anammox bacteria (Zhu et al., 2008). In municipal WWTPs, nitrite is mainly produced by partial nitrification $\left(\mathrm{NH}_{4}^{+} \rightarrow \mathrm{NO}_{2}^{-}\right.$) (Yang et al., 2007) and partial denitrification $\left(\mathrm{NO}_{3}^{-} \rightarrow \mathrm{NO}_{2}^{-}\right.$) (Cao et al., 2013), of which the reduction rate of $\mathrm{NO}_{2}^{-}\left(\mathrm{NO}_{2}^{-} \rightarrow \mathrm{NO} / \mathrm{N}_{2}\right)$ by heterotrophic denitrification is 1.25-6.5 times higher than the oxidation rate of $\mathrm{NO}_{2}^{-}\left(\mathrm{NO}_{2}^{-} \rightarrow \mathrm{NO}_{3}^{-}\right)$by autotrophic nitrification (Yang et al., 2007;
Peng and Zhu, 2006). Thus, partial nitrification may produce nitrite for anammox bacteria. It had been found that nitrification produces nitrite for anammox bacteria in nature ecosystems, e.g. marine (Lam et al., 2007; Kuypers et al., 2005), freshwater (Wang et al., 2012a), and soil (Zhu et al., 2011b). Therefore, the potential synergism and competition of anammox bacteria and nitrifiers for nitrite was investigated. The correlation analysis showed that anammox bacteria and nitrifiers established a well-cooperation symbiosis community (Table S7).

Nitrite is mainly provided by oxidation of ammonia by ammonia oxidation bacteria (AOB) and archaea (AOA) in nitrification, after which it is oxidized to nitrate by nitrite oxidation bacteria (NOB) (Peng and Zhu, 2006). Real-time qPCR assays targeting the ammonia monooxygenase (AMO) functional gene (amoA) which is the key enzyme of ammonia oxidation were performed (Fig. 5-I). The number of bacterial amoA copies $\left(3.9 \times 10^{6}-2.0 \times 10^{10}\right.$ copies $\mathrm{g}^{-1}, 0.05-6.10 \%$ of the total bacteria; Fig. 5-I, Fig. S3) in summer

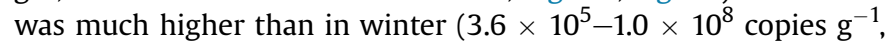
$0.04-0.72 \%$ of the total bacteria; Fig. 5-I, Fig. S3). In contrast, the number of archaeal amoA genes ranged from $6.5 \times 10^{4}$ to $9.4 \times 10^{6}$ copies $\mathrm{g}^{-1}$ in summer, and from $1.4 \times 10^{4}$ and $1.5 \times 10^{6}$ copies $^{-1}$ in winter. In all the WWTPs samples, AOB showed a higher abundance than $A O A$, indicating that $A O B$ provided more nitrite for anammox than AOA.

NOB competes with anammox bacteria for nitrite. The abundance of two common NOB, Nitrospira and Nitrobacter, were analyzed using qPCR (Fig. 5-II). The abundance of total NOB was much higher (up to $7.2 \times 10^{4}$ times) than that of anammox bacteria in all samples, especially in summer. The number of Nitrospira genes was $1.6 \times 10^{8}-4.2 \times 10^{11}$ copies $\mathrm{g}^{-1}$ in summer and $3.5 \times 10^{7}-1.2 \times 10^{10}$ copies $\mathrm{g}^{-1}$ in winter $(1.37-60.69 \%$ and $1.16-74.70 \%$ of the total bacteria, respectively; Fig. 5-II, Fig. S3), while the number of Nitrobacter was $3.7 \times 10^{7}-2.5 \times 10^{10}$ copies $\mathrm{g}^{-1}$ in summer and $1.1 \times 10^{7}-4.7 \times 10^{9}$ copies $\mathrm{g}^{-1}$ in winter (0.50-6.23\%o and $0.25-28.11 \%$, respectively). This indicated that Nitrospira maybe a major competitor for nitrite.

\section{Discussion}

Anammox bacterial biodiversity, activity, and contribution to $\mathrm{N}$ loss have been widely analyzed in marine (Ward, 2013; Voss and Montoya, 2009; Jetten et al., 2003) and inland waters (Zhu et al., 2013; Schubert et al., 2006; Wang et al., 2012a; Zhang et al., 2007). However, the distribution and role of anammox in anthropogenic ecosystems still remains uncertain. In this study, the anammox bacterial abundance, biodiversity, activity, and role were determined in diverse treatment units of municipal WWTPs. Anammox bacteria were detected in all samples tested, regardless of the oxygen concentration, substrate loadings, and operating conditions. These findings revealed that anammox bacteria was potentially widespread in WWTPs, and had a positive effect on $\mathrm{N}$ removal, contributing $2.05-6.86 \%$ and $1.71-7.26 \%$ to total $\mathrm{N}_{2}$ production in winter and summer, respectively. The ecological habitats of anammox bacteria in anthropogenic ecosystems are much more abundant than previous assumption.

The ${ }^{15} \mathrm{~N}$ isotopic tracing analysis showed that the rate and contribution of anammox in municipal WWTPs were $0.08-1.2 \mu \mathrm{mol} \mathrm{N} \mathrm{g}^{-1} \mathrm{~h}^{-1}$ and $1.71-7.26 \%$ to $\mathrm{N}_{2}$ production, respectively. These values were in the same range as the reported values in freshwater, estuarine, and other anthropogenic environments (Zhu et al., 2013; Schubert et al., 2006; Wang et al., 2012a; Zhu et al., 2011a, Zhu et al., 2011b; Risgaard-Petersen et al., 2004; Erler et al., 2008; Dale et al., 2009). Previous studies found that anammox bacterial activity could not be detected at concentrations below $10^{10}-10^{11}$ cells $\mathrm{mL}^{-1}$ which was defined as the quorum 


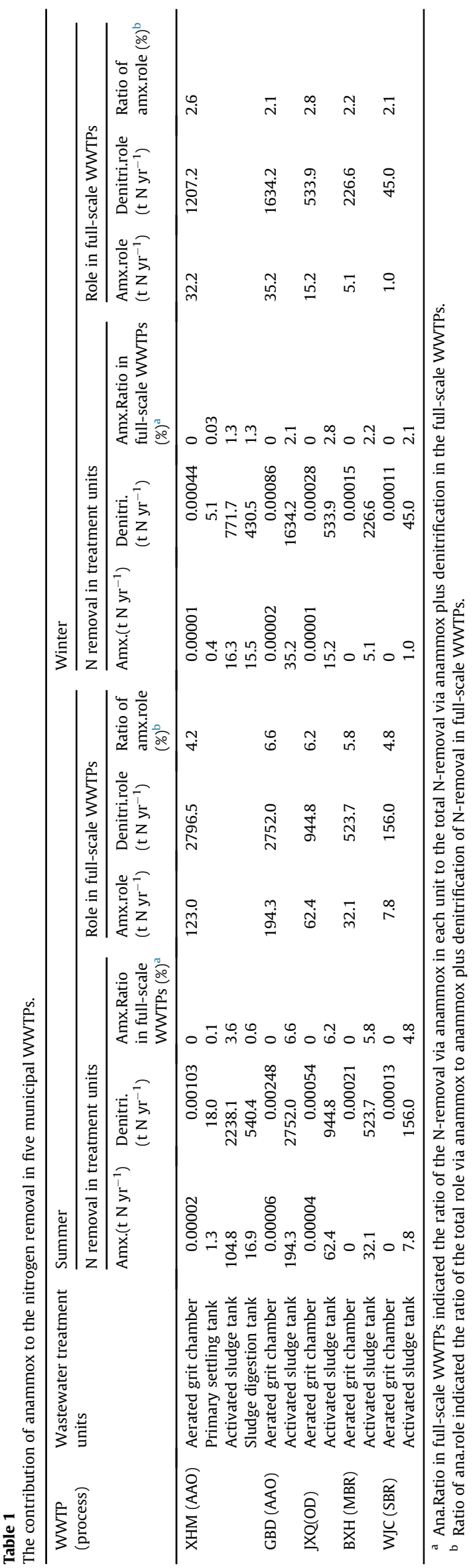

sensing system, a density-dependent phenomenon of anammox cells (Strous et al., 1999; Ding et al., 2013). This study used a new technique to detect anammox bacteria at a low threshold of $10^{2}-10^{4}$ cells $\mathrm{mL}^{-1}$, and the samples were incubated with $\mathrm{NH}_{4}^{+}$plus $\mathrm{NO}_{3}^{-}$to reach a final concentration of $50 \mathrm{mg} \mathrm{L}^{-1}$, so that anammox and denitrification in municipal WWTPs obtained from the potential rate measurements were not seriously overestimated. Moreover, the specific cell anammox rates $\left(2.36-9.52 \mathrm{fmol} \mathrm{cell}^{-1}\right.$ day $^{-1}$ ) were comparable to the anammox rates found in freshwater systems and marine water columns $\left(2-21 \mathrm{fmol} \mathrm{cell}^{-1}\right.$ day $^{-1}$ (Kuypers et al., 2003; Zhu et al., 2013; Strous et al., 1999)). The possible reasons for the substantial anammox rate and contribution in municipal WWTPs may be the continuous introduction of ammonia-substrate via municipal wastewater and the production of nitrite-substrate by microbial populations via artificial enhancement, especially by nitrifiers (Table S7).

In addition to the anammox rate, the diversity of anammox bacteria in municipal WWTPs was investigated. The anammox bacterial exhibited low biodiversity in marine ecosystems, and the diversity is restricted to the Scalindua genus only (Schmid et al., 2007). In contrast, a high biodiversity was observed in freshwater ecosystems (e.g. Scalindua genus in Lake Tanganyika (Schubert et al., 2006); Brocadia in Xinyi river sediments (Zhang et al., 2007); two genera Brocadia and Kuenenia in both Pearl river sediments and Baiyangdian Lake (Zhu et al., 2013; Wang et al., 2012a)). In our previous studies, a high biodiversity with four genera of anammox bacteria, 'Brocadia', 'Kuenenia', 'Anammoxoglobus' and 'Jettenia' was observed in soil ecosystems (Zhu et al., 2011b). However, the findings in anthropogenic ecosystems, such as constructed wetlands (Zhu et al., 2011a) and plant soil (Hu et al., 2011) showed that the biodiversity of anammox bacteria was very low, with only two genera, 'Brocadia' and 'Kuenenia' being detected. Further investigation on the fundamental factors controlling the biogeography distribution of anammox bacteria should be conducted.

Previous studies found that anammox bacteria favored high nitrogen loading (500-1500 $\mathrm{mg} \mathrm{NH}_{4}^{+}-\mathrm{N} \mathrm{L}^{-1}$; (Lackner et al., 2014)). However, in this study, anammox in municipal WWTPs were present at high abundance $10^{5}-10^{7}$ copies $g^{-1}$ even at low nitrogen loadings (2.1-51.0 $\left.\mathrm{mg} \mathrm{L}^{-1}\right)$. The potentially widespread of anammox bacteria was reflected by the low half-saturation constant for substrates $\left(K_{s}\left(\mathrm{NH}_{4}^{+}\right) \leq 7 \mu \mathrm{M}\right.$ (Jetten et al., 2005); $K_{s}\left(\mathrm{NO}_{2}^{-}\right)<5 \mu \mathrm{M}$ (Brocadia) and 0.2-0.3 $\mu \mathrm{M}$ (Kuenenia) (Kartal et al., 2012)), which could be attributed to two unique functional structures of anammox bacteria: (i) the anammoxosome membrane, which contains ladderane lipids and a dense and low permeable membrane that can maintain concentration gradients during the exceptionally slow anammox metabolism (Sinninghe Damste et al., 2002); (ii) ammonium transporters (Amt) and nitrite transporters (FocA, NarK), which regulate the movement of ammonium and nitrite through the dense membrane (Strous et al., 2006; van Niftrik and Jetten, 2012). The unique eco-physiological features of anammox bacteria enabled their adaptation to low-substrate conditions and contributed to their widespread occurrence in anthropogenic ecosystems with low nitrogen loading.

This study showed that anammox bacteria were still active in aerobic tanks (DO $>2 \mathrm{mg} \mathrm{L}^{-1}$ ) with $0.12-1.13 \mu \mathrm{mol} \mathrm{N} \mathrm{g}^{-1} \mathrm{~h}^{-1}$ in summer and $0.08-0.25 \mu \mathrm{mol} \mathrm{N} \mathrm{g}{ }^{-1} \mathrm{~h}^{-1}$ in winter, which was contrary to the conventional concept that anammox only occurred in anoxic/anaerobic conditions and were temporarily inhibited by oxygen as little as $1 \mu \mathrm{M}$ (Strous et al., 1997a,b). Moreover, sludge size could provide an aerobic/anoxic/anaerobic micro-environment to satisfy the anammox process, such as the completely autotrophic nitrogen-removal over nitrite (CANON) process (Third et al., 2001). However, the distribution of sludge sizes in aerobic tanks 


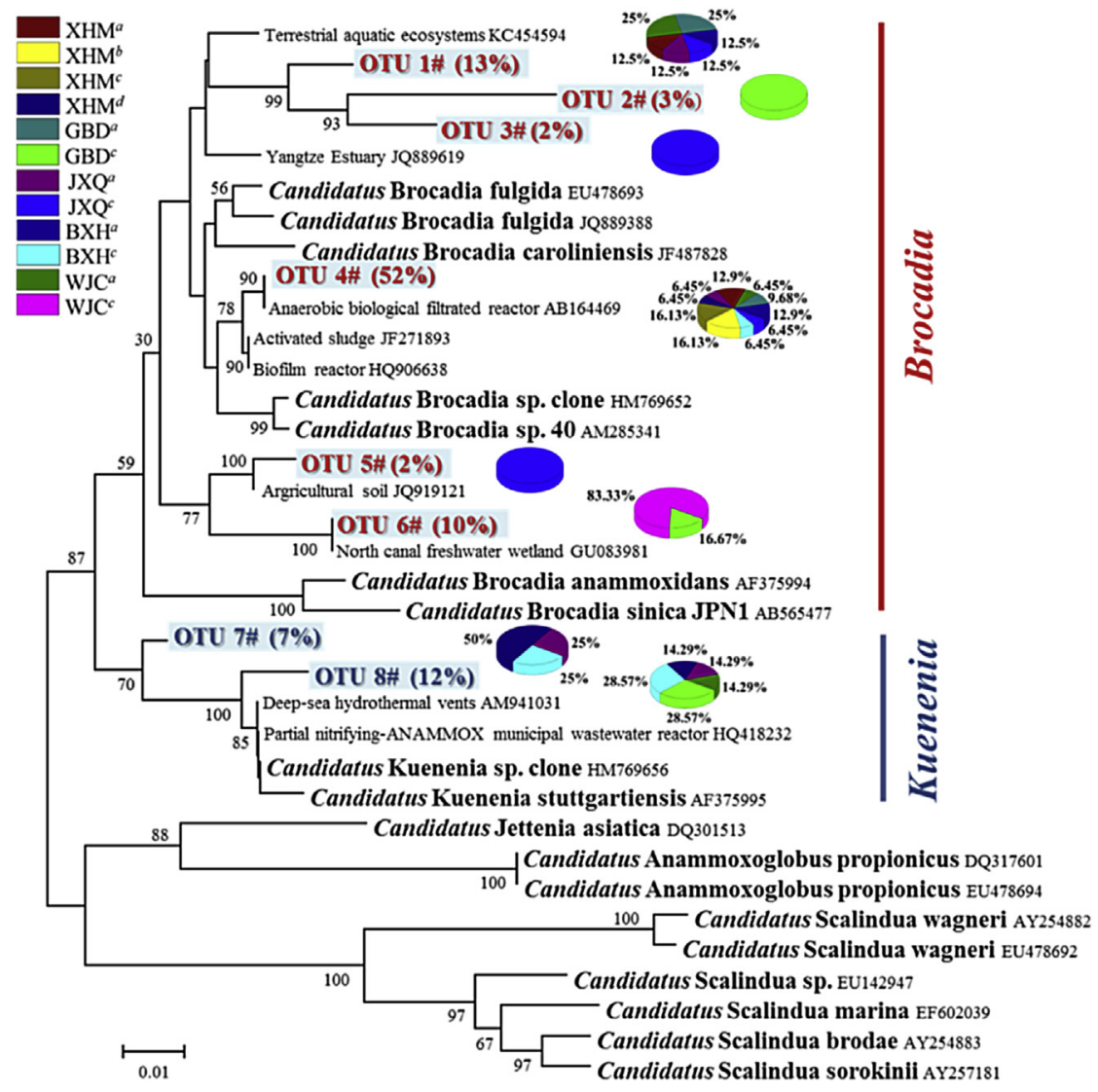

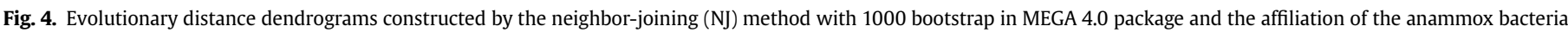

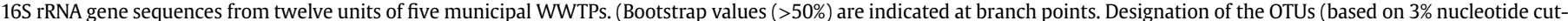

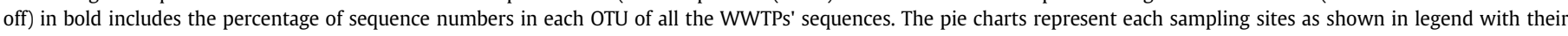
percentages of sequence numbers in each OTU).

(DO $>2 \mathrm{mg} \mathrm{L}^{-1}$ ) in this study was only 79.4-91.2 $\mu \mathrm{m}$ (Fig. S4), which was much smaller than the reported sizes of anammox zoogloea/granular sludge $(1.0-6.4 \mathrm{~mm})$ (Vazquez-Padin et al., 2010; Figueroa et al., 2012; Tang et al., 2011). Therefore, sludge size was probably not associated with the occurrence of anammox in the aerobic units of municipal WWTPs.

In addition, the results provided the evidence of potential synergism and competition between anammox bacteria and nitrifying partners for nitrite substrate. During nitrification, AOA and AOB oxidize ammonia to toxic nitrite, which is removed by anammox (Lam et al., 2007; Woebken et al., 2007; Lam et al., 2009). AOB showed higher abundance than AOA, indicating that they may play a more important role in nitrite production. NOB may be a strong competitor for nitrite, especially the species Nitrospira. Although the abundance of NOB $\left(4.72 \times 10^{7}-4.46 \times 10^{11}\right.$ copies $\left.\mathrm{g}^{-1}\right)$ was much higher than that of anammox bacteria, the $K_{s}\left(\mathrm{NO}_{2}^{-}\right)$of anammox bacteria was lower than that of Nitrospira $(10 \mu \mathrm{M})$ and Nitrobacter (21-135 $\mu \mathrm{M})$ (Blackburne et al., 2007). The lower $K_{s}$ value equipped anammox bacteria with a stronger ability to acquire the substrate than their competitors under low substrate conditions.

From the discovery of anammox in man-made systems twenty years ago (Muldera et al., 1995), in marine systems a decade ago (Dalsgaard et al., 2003) and in freshwater systems two years ago (Zhu et al., 2013), our understanding of anammox has been regularly updated. In anthropogenic ecosystems, the anammox process brings WWTP more potentialities to energy self-sustaining and greenhouse gas mitigation, owning to significant reduction of aeration energy, no requirement of organic carbon source, and increasing biogas production. However, the application of anammox is still limited to ammonia rich wastewater treatment due to its low growth rate and biomass yield (Siegrist et al., 2008). This study showed that active anammox bacteria widely existed in WWTPs with low-strength loading and contributed to $2 \%-7 \% \mathrm{~N}$ removal, which revealed the great potential of expanding the anammox process to low-strength wastewater treatment systems. Two questions should be elucidated in further studies: (i) what is the key factor (except DO, substrate loading, and sludge size) limiting the anammox rate in municipal WWTPs? and (ii) how does anammox functions in the reduction of greenhouse gas (especially $\mathrm{N}_{2} \mathrm{O}$ ) in WWTPs?

\section{Conclusion}

The spatio-temporal abundance, activity, and biodiversity of anammox bacteria in full-scale municipal wastewater treatment plants (WWTPs) via traditional nitrification-denitrification route were investigated with molecular and isotopic tracing techniques. There were three main conclusions:

- The anammox bacteria were widespread in diverse treatment units of municipal WWTPs, regardless of the oxygen content

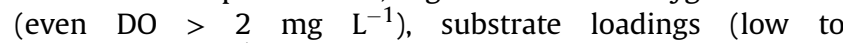
2.1-51.0 $\mathrm{mg} \mathrm{N} \mathrm{L}^{-1}$ ), seasonal condition (winter and summer) or operating process (AAO, OD, SBR, and MBR), with the abundance of $10^{5}-10^{7}$ hzs gene copies $\mathrm{g}^{-1}$. 

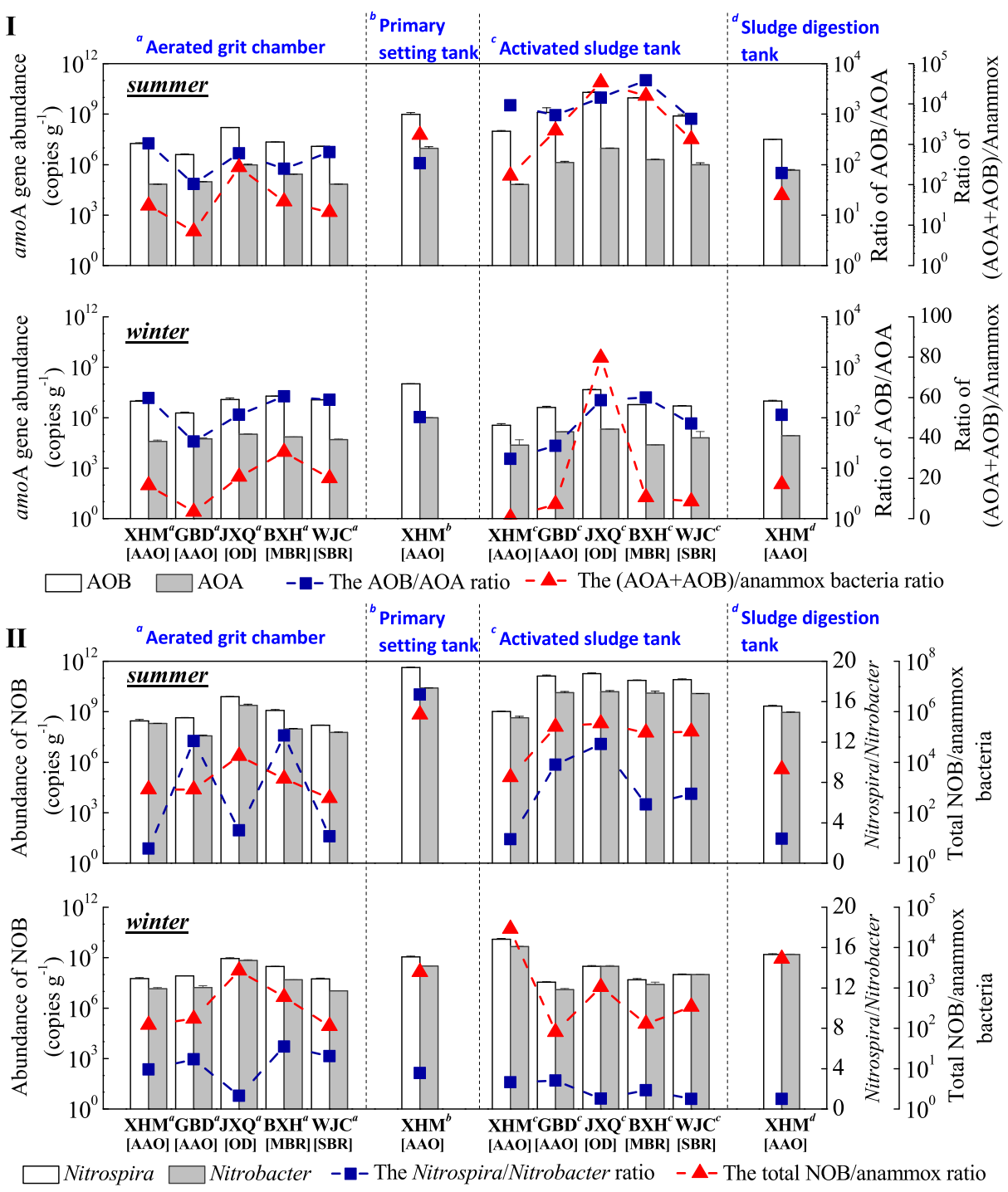

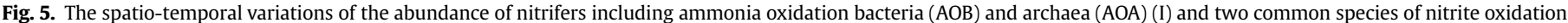
bacteria (NOB): Nitrospira \& Nitrobacter (II), and the related ratios among anammox bacteria, AOB, AOA, and NOB in municipal WWTPs.

- The ${ }^{15} \mathrm{~N}$-isotope tracing analysis revealed that the anammox rates of WWTPs ranged from 0.08 to $0.36 \mu \mathrm{mol} \mathrm{N} \mathrm{g} \mathrm{g}^{-1} \mathrm{~h}^{-1}$ in winter and $0.12-1.20 \mu \mathrm{mol} \mathrm{N} \mathrm{g} \mathrm{N}^{-1} \mathrm{~h}^{-1}$ in summer with the contributions of $2.05-6.86 \%$ and $1.71-7.26 \%$ to $\mathrm{N}_{2}$ production, respectively.

- The exploration of potential interspecies relationships indicated that $\mathrm{AOB}$, rather than $\mathrm{AOA}$, was the major nitrite-substrate producer for anammox during nitrification, while Nitrospira, a NOB, maybe the major competitor for nitrite.

\section{Acknowledgments}

The isotopic measurements were conducted in the key laboratory of Tibetan environment changes and land surface processes (TEL), Institute of Tibetan Plateau Research, Chinese Academy of Sciences. We greatly thank Dr. Shujun Zhang, Dr. Xiyao Li, Dr. Fangxu Jia, and Mr. Pengfei Jin for their kind help in sampling and analysis on this work. This research is financially supported by the National Science Foundation of China (21177005) and Open Project of State Key Laboratory of Urban Water Resource and Environment, Harbin Institute of Technology (Grant No QAK201502). The author
Guibing Zhu gratefully acknowledges the support of National Natural Science Foundation of China (41322012) and Alexander von Humboldt Foundation Research Fellowship (1152633).

\section{Appendix A. Supplementary data}

Supplementary data related to this article can be found at http:// dx.doi.org/10.1016/j.watres.2015.07.005.

\section{References}

Ahn, J.H., Yu, R., Chandran, K., 2008. Distinctive microbial ecology and biokinetics of autotrophic ammonia and nitrite oxidation in a partial nitrification bioreactor. Biotechnol. Bioeng. 100 (6), 1078-1087.

APHA, AWWA, WEF (Eds.), 1995. Standard Methods for the Examination of Water and Wastewater, 19th ed. P.H.A.A.W.W.A.W.E. Federation, Washington DC, USA.

Arrigo, K.R., 2005. Marine microorganisms and global nutrient cycles. Nature 437 (7057), 349-355.

Blackburne, R., Vadivelu, V.M., Yuan, Z, Keller J. 2007. Kinetic characterisation of an enriched Nitrospira culture with comparison to Nitrobacter. Water Res. 41 (14), 3033-3042.

Burgin, A.J., Hamilton, S.K., 2007. Have we overemphasized the role of denitrification in aquatic ecosystems? A review of nitrate removal pathways. Front. Ecol. Environ. 5 (2), 89-96.

Cao, S., Wang, S., Peng, Y., Wu, C., Du, R., Gong, L., Ma, B., 2013. Achieving partial 
denitrification with sludge fermentation liquid as carbon source: the effect of seeding sludge. Bioresour. Technol. 149, 570-574.

Dale, O.R., Tobias, C.R., Song, B., 2009. Biogeographical distribution of diverse anaerobic ammonium oxidizing (anammox) bacteria in Cape Fear River Estuary. Environ. Microbiol. 11 (5), 1194-1207.

Dalsgaard, T., Canfield, D.E., Petersen, J., Thamdrup, B., Acuña-González, J., 2003. N 2 production by the anammox reaction in the anoxic water column of Golfo Dulce, Costa Rica. Nature 422 (6932), 606-608.

Ding, S., Zheng, P., Lu, H., Chen, J., Mahmood, Q., Abbas, G., 2013. Ecological characteristics of anaerobic ammonia oxidizing bacteria. Appl. Microbiol. Biotechnol. 97 (5), 1841-1849.

Erler, D.V., Eyre, B.D., Davison, L., 2008. The contribution of anammox and denitrification to sediment $\mathrm{N}_{2}$ production in a surface flow constructed wetland. Environ. Sci. Technol. 42 (24), 9144-9150.

Falkowski, P.G., Fenchel, T., Delong, E.F., 2008. The microbial engines that drive earth's biogeochemical cycles. Science 320 (5879), 1034-1039.

Figueroa, M., Ramon Vazquez-Padin, J., Mosquera-Corral, A., Luis Campos, J., Mendez, R., 2012. Is the CANON reactor an alternative for nitrogen removal from pre-treated swine slurry? Biochem. Eng. J. 65, 23-29.

Geets, J., de Cooman, M., Wittebolle, L., Heylen, K., Vanparys, B., De Vos, P., Verstraete, W., Boon, N., 2007. Real-time PCR assay for the simultaneous quantification of nitrifying and denitrifying bacteria in activated sludge. Appl. Microbiol. Biotechnol. 75 (1), 211-221.

Hannig, M., Lavik, G., Kuypers, M., Woebken, D., Martens-Habbena, W., Jürgens, K., 2007. Shift from denitrification to anammox after inflow events in the central Baltic Sea. Limnol. Oceanogr. 52 (4), 1336-1345.

Hu, B.L., Rush, D., van der Biezen, E., Zheng, P., van Mullekom, M., Schouten, S., Sinninghe Damsté, J.S., Smolders, A.J.P., Jetten, M.S.M., Kartal, B., 2011. New anaerobic, ammonium-oxidizing community enriched from peat soil. Appl. Environ. Microbiol. 77 (3), 966-971.

IPCC, 2001. Climate Change 2001: the Scientific Basis. Cambridge University Press, Cambridge.

Jetten, M.S., Cirpus, I., Kartal, B., van Niftrik, L., van de Pas-Schoonen, K.T., Sliekers, O., Haaijer, S., van der Star, W., Schmid, M., van de Vossenberg, J., Schmidt, I., Harhangi, H., van Loosdrecht, M., Gijs Kuenen, J., Op den Camp, H., Strous, M., 2005. 1994-2004: 10 years of research on the anaerobic oxidation of ammonium. Biochem. Soc. T 33 (1), 119-123.

Jetten, M.S., Sliekers, O., Kuypers, M., Dalsgaard, T., van Niftrik, L., Cirpus, I., van de Pas-Schoonen, K., Lavik, G., Thamdrup, B., Le Paslier, D., Op den Camp, H.J., Hulth, S., Nielsen, L.P., Abma, W., Third, K., Engström, P., Kuenen, J.G., Jørgensen, B.B., Canfield, D.E., Sinninghe Damsté, J.S., Revsbech, N.P., Fuerst, J., Weissenbach, J., Wagner, M., Schmidt, I., Schmid, M., Strous, M., 2003. Anaerobic ammonium oxidation by marine and freshwater planctomycete-like bacteria. Appl. Microbiol. Biotechnol. 63 (2), 107-114.

Kartal, B., Maalcke, W.J., de Almeida, N.M., Cirpus, I., Gloerich, J., Geerts, W., Op den Camp, H.J., Harhangi, H.R., Janssen-Megens, E.M., Francoijs, K.J., Stunnenberg, H.G., Keltjens, J.T., Jetten, M.S., Strous, M., 2011. Molecular mechanism of anaerobic ammonium oxidation. Nature 479 (7371), 127-130.

Kartal, B., van Niftrik, L., Keltjens, J.T., Op den Camp, H.J., Jetten, M.S., 2012. Anammox--growth physiology, cell biology, and metabolism. Adv. Microb. Physiol. 60, 211-262.

Koike, S., Krapac, I.G., Oliver, H.D., Yannarell, A.C., Chee-Sanford, J.C., Aminov, R.I., Mackie, R.I., 2007. Monitoring and source tracking of tetracycline resistance genes in lagoons and groundwater adjacent to swine production facilities over a 3-year period. Appl. Environ. Microbiol. 73 (15), 4813-4823.

Kuypers, M.M., Lavik, G., Woebken, D., Schmid, M., Fuchs, B.M., Amann, R., Jorgensen, B.B., Jetten, M.S., 2005. Massive nitrogen loss from the Benguela upwelling system through anaerobic ammonium oxidation. Proc. Natl. Acad. Sci. U. S. A. 102 (18), 6478-6483.

Kuypers, M.M., Sliekers, A.O., Lavik, G., Schmid, M., Jorgensen, B.B., Kuenen, J.G., Sinninghe Damste, J.S., Strous, M., Jetten, M.S., 2003. Anaerobic ammonium oxidation by anammox bacteria in the Black Sea. Nature 422 (6932), 608-611.

Lackner, S., Gilbert, E.M., Vlaeminck, S.E., Joss, A., Horn, H., van Loosdrecht, M.C.M., 2014. Full-scale partial nitritation/anammox experiences - an application survey. Water Res. 55, 292-303.

Lam, P., Jensen, M.M., Lavik, G., McGinnis, D.F., Müller, B., Schubert, C.J., Amann, R., Thamdrup, B., Kuypers, M.M., 2007. Linking crenarchaeal and bacterial nitrification to anammox in the Black Sea. Proc. Natl. Acad. Sci. U. S. A. 104 (17), 7104-7109.

Lam, P., Lavik, G., Jensen, M.M., van de Vossenberg, J., Schmid, M., Woebken, D., Gutierrez, D., Amann, R., Jetten, M.S., Kuypers, M.M., 2009. Revising the nitrogen cycle in the Peruvian oxygen minimum zone. Proc. Natl. Acad. Sci. U. S. A. 106 (12), 4752-4757.

Muldera, A., Graafb, A. A. v. d., Robertsonb, L.A., Kuenen, J.G., 1995. Anaerobic ammonium oxidation discovered in a denitrifying fluidized bed reactor. FEMS Microbiol. Ecol. 16 (3), 177-183.

Peng, Y., Zhu, G., 2006. Biological nitrogen removal with nitrification and denitrification via nitrite pathway. Appl. Microbiol. Biotechnol. 73 (1), 15-26.

Pitcher, A., Villanueva, L., Hopmans, E.C., Schouten, S., Reichart, G.J., Sinninghe Damste, J.S., 2011. Niche segregation of ammonia-oxidizing archaea and anammox bacteria in the Arabian Sea oxygen minimum zone. ISME J. 5 (12), 1896-1904.

Risgaard-Petersen, N., Meyer, R.L., Schmid, M., Jetten, M.S.M., Enrich-Prast, A., Rysgaard, S., Revsbech, N.P., 2004. Anaerobic ammonium oxidation in an estuarine sediment. Aquat. Microb. Ecol. 36 (3), 293-304.
Schloss, P.D., Handelsman, J., 2005. Introducing DOTUR, a computer program for defining operational taxonomic units and estimating species richness. Appl. Environ. Microbiol. 71 (3), 1501-1506.

Schmid, M.C., Risgaard-Petersen, N., van de Vossenberg, J., Kuypers, M.M., Lavik, G., Petersen, J., Hulth, S., Thamdrup, B., Canfield, D., Dalsgaard, T., Rysgaard, S., Sejr, M.K., Strous, M., den Camp, H.J., Jetten, M.S., 2007. Anaerobic ammonium-oxidizing bacteria in marine environments: widespread occurrence but low diversity. Environ. Microbiol. 9 (6), 1476-1484.

Schubert, C.J., Durisch-Kaiser, E., Wehrli, B., Thamdrup, B., Lam, P., Kuypers, M.M., 2006. Anaerobic ammonium oxidation in a tropical freshwater system (Lake Tanganyika). Environ. Microbiol. 8 (10), 1857-1863.

Siegrist, H., Salzgeber, D., Eugster, J., Joss, A., 2008. Anammox brings WWTP closer to energy autarky due to increased biogas production and reduced aeration energy for N-removal. Water Sci. Technol. 57 (3), 383-388.

Sinninghe Damste, J.S., Strous, M., Rijpstra, W.I.C., Hopmans, E.C., Geenevasen, J.A.J. van Duin, A.C.T., van Niftrik, L.A., Jetten, M.S.M., 2002. Linearly concatenated cyclobutane lipids form a dense bacterial membrane. Nature 419 (6908), 708-712.

Strous, M., Fuerst, J.A., Kramer, E.H., Logemann, S., Muyzer, G., van de Pas-Schoonen, K.T., Webb, R., Kuenen, J.G., Jetten, M.S., 1999. Missing lithotroph identified as new planctomycete. Nature 400 (6743), 446-449.

Strous, M., Pelletier, E., Mangenot, S., Rattei, T., Lehner, A., Taylor, M.W., Horn, M. Daims, H., Bartol-Mavel, D., Wincker, P., Barbe, V., Fonknechten, N., Vallenet, D. Segurens, B., Schenowitz-Truong, C., Medigue, C., Collingro, A., Snel, B., Dutilh, B.E., Op den Camp, H.J., van der Drift, C., Cirpus, I., van de Pas-Schoonen, K.T., Harhangi, H.R., van Niftrik, L., Schmid, M., Keltjens, J., van de Vossenberg, J., Kartal, B., Meier, H., Frishman, D., Huynen, M.A., Mewes, H.W., Weissenbach, J., Jetten, M.S., Wagner, M., Le Paslier, D., 2006. Deciphering the evolution and metabolism of an anammox bacterium from a community genome. Nature 440 (7085), 790-794.

Strous, M., Van Gerven, E., Kuenen, J.G., Jetten, M., 1997a. Effects of aerobic and microaerobic conditions on anaerobic ammonium-oxidizing (anammox) sludge. Appl. Environ. Microbiol. 63 (6), 2446-2448.

Strous, M., Van Gerven, E., Zheng, P., Kuenen, J.G., Jetten, M.S.M., 1997b. Ammonium removal from concentrated waste streams with the anaerobic ammonium oxidation (anammox) process in different reactor configurations. Water Res. 31 (8), 1955-1962.

Tal, Y., Watts, J.E.M., Schreier, H.J., 2006. Anaerobic ammonium-oxidizing (Anammox) bacteria and associated activity in fixed-film biofilters of a marine recirculating aquaculture system. Appl. Environ. Microbiol. 72 (4), 2896-2904.

Tamura, K., Dudley, J., Nei, M., Kumar, S., 2007. MEGA4: molecular evolutionary genetics analysis (MEGA) software version 4.0. Mol. Biol. Evol. 24 (8), 1596-1599.

Tang, C.J., Zheng, P., Wang, C.H., Mahmood, Q., Zhang, J.Q., Chen, X.G., Zhang, L., Chen, J.W., 2011. Performance of high-loaded ANAMMOX UASB reactors containing granular sludge. Water Res. 45 (1), 135-144.

Thamdrup, B., Dalsgaard, T., 2002. Production of $\mathrm{N}_{2}$ through anaerobic ammonium oxidation coupled to nitrate reduction in marine sediments. Appl. Environ. Microbiol. 68 (3), 1312-1318.

Third, K.A., Sliekers, A.O., Kuenen, J.G., Jetten, M.S.M., 2001. The CANON system (completely autotrophic nitrogen-removal over nitrite) under ammonium limitation: Interaction and competition between three groups of bacteria. Syst. Appl. Microbiol. 24 (4), 588-596.

Thompson, J.D., Gibson, T.J., Plewniak, F., Jeanmougin, F., Higgins, D.G., 1997. The CLUSTAL_X windows interface: flexible strategies for multiple sequence alignment aided by quality analysis tools. Nucleic Acids Res. 25 (24), 4876-4882.

van Kessel, M.A.H.J., Harhangi, H.R., van de Pas-Schoonen, K., van de Vossenberg, J. Flik, G., Jetten, M.S.M., Klaren, P.H.M., Op den Camp, H.J.M., 2010. Biodiversity of $\mathrm{N}$-cycle bacteria in nitrogen removing moving bed biofilters for freshwater recirculating aquaculture systems. Aquaculture 306 (1-4), 177-184.

van Niftrik, L., Jetten, M.S., 2012. Anaerobic ammonium-oxidizing bacteria: unique microorganisms with exceptional properties. Microbiol. Mol. Biol. R. 76 (3), 585-596.

Vazquez-Padin, J., Mosquera-Corral, A., Luis Campos, J., Mendez, R., Revsbech, N.P. 2010. Microbial community distribution and activity dynamics of granular biomass in a CANON reactor. Water Res. 44 (15), 4359-4370.

Voss, M., Montoya, J.P., 2009. Nitrogen cycle: oceans apart. Nature 461 (7260), 49-50.

Wang, S.Y., Zhu, G.B., Peng, Y.Z., Jetten, M.S.M., Yin, C.Q., 2012a. Anammox bacterial abundance, activity, and contribution in riparian sediments of the Pearl River Estuary. Environ. Sci. Technol. 46 (16), 8834-8842.

Wang, S.Y., Wang, Y., Feng, X.J., Zhai, L.M., Zhu, G.B., 2011. Quantitative analyses of ammonia-oxidizing Archaea and bacteria in the sediments of four nitrogen-rich wetlands in China. Appl. Microbiol. Biotechnol. 90 (2), 779-787.

Wang, Y., Zhu, G., Harhangi, H.R., Zhu, B., Jetten, M.S., Yin, C., Op den Camp, H.J., 2012b. Co-occurrence and distribution of nitrite-dependent anaerobic ammonium and methane-oxidizing bacteria in a paddy soil. FEMS Microbiol. Lett. 336 (2), 79-88.

Ward, B.B., 2013. How nitrogen is lost. Science 341 (6144), 352-353.

Ward, B.B., Devol, A.H., Rich, J.J., Chang, B.X., Bulow, S.E., Naik, H., Pratihary, A., Jayakumar, A., 2009. Denitrification as the dominant nitrogen loss process in the Arabian Sea. Nature 461 (7260), 78-81.

Woebken, D., Fuchs, B.M., Kuypers, M.M., Amann, R., 2007. Potential interactions of particle-associated anammox bacteria with bacterial and archaeal partners in the Namibian upwelling system. Appl. Environ. Microbiol. 73 (14), 4648-4657. 
Yang, Q., Peng, Y., Liu, X., Zeng, W., Mino, T., Satoh, H., 2007. Nitrogen removal via nitrite from municipal wastewater at low temperatures using real-time control to optimize nitrifying communities. Environ. Sci. Technol. 41 (23), 8159-8164.

Zhang, Y., Ruan, X.H., Op den Camp, H.J., Smits, T.J., Jetten, M.S., Schmid, M.C., 2007. Diversity and abundance of aerobic and anaerobic ammonium-oxidizing bacteria in freshwater sediments of the Xinyi River (China). Environ. Microbiol. 9 (9), 2375-2382.

Zhu, G.B., Wang, S.Y., Feng, X.J., Fan, G.N., Jetten, M.S.M., Yin, C.Q., 2011a. Anammox bacterial abundance, biodiversity and activity in a constructed wetland. Environ. Sci. Technol. 45 (23), 9951-9958.
Zhu, G.B., Wang, S.Y., Wang, Y., Wang, C.X., Risgaard-Petersen, N., Jetten, M.S.M., Yin, C.Q., 2011b. Anaerobic ammonia oxidation in a fertilized paddy soil. ISME J. 5 (12), 1905-1912.

Zhu, G., Peng, Y., Li, B., Guo, J., Yang, Q., Wang, S., 2008. Biological removal of nitrogen from wastewater. Rev. Environ. Contam. T. 192, 159-195.

Zhu, G., Wang, S., Wang, W., Wang, Y., Zhou, L., Jiang, B., Op den Camp, H.J.M., Risgaard-Petersen, N., Schwark, L., Peng, Y., Hefting, M.M., Jetten, M.S.M., Yin, C., 2013. Hotspots of anaerobic ammonium oxidation at land-freshwater interfaces. Nat. Geosci. 6 (2), 103-107. 